\title{
The Denationalization and Agencification of Net Neutrality Policy in Lithuania
}

\section{Deimantas Jastramskis*}

\section{SUMMARY}

This paper focuses on the making of communications policy in Lithuania, specifically regarding net neutrality. The study employs a multiple stream model to analyze the conditions of the political process and the activity of political actors. The paper claims that the Lithuanian communications policy has become essentially denationalized since the country's accession to the European Union. The issue of net neutrality policy has been framed in the context of EU policy, while the national agenda of net neutrality policy lost its significance. The denationalization of the net neutrality policy-making was harmonized with the agencification of policy formulation stage.

Keywords: communications policy, net neutrality, regulation, broadband internet, multiple streams model.

\section{Introduction}

The human right to seek, receive, and impart information through any media and regardless of any frontiers is enshrined in the Universal Declaration of Human Rights (The United Nations General Assembly, 1948). This right becomes a certain political principle in democratic countries, when some attempts are made to regulate the access to information across various means of communications. The most common political principles are these: first, providing universal access to infrastructures, and second, ensuring the availability of affordable basic-use technology and levels of services (Picard, Pickard, 2017). The implementation of these principles

\footnotetext{
* Deimantas Jastramskis, Associate Professor, Faculty of Communication,
} Vilnius University, Lithuania. E-mail: deimantas.jastramskis@kf.vu.lt 
requires not only investments, protection from market failures, sufficient competition, and consumers' economic capacity as well as a particular level of literacy to use advanced technologies. The supervision of market participants and the ensuring of equal access to the benefits of communication are also needed.

In the context of equal consumers' opportunities to access and use data from various internet sources, the issue of net neutrality inevitably appears on the political agenda. The solution to this problem mainly depends on the discussion whether all the legal flows of information (content) on the internet should be treated equally by the internet service providers or are some flows "more equal" than others. Besides the equal treatment of all kinds of content, the net neutrality principle also means that any preferential treatment of specific "services, applications, and devices that can be integrated into the network infrastructure" should be forbidden (Meinrath, Pickard, 2008: 11). Policy decisions regarding net neutrality are quite different across the democratic countries and depend on which interest, that of private business or public, wins the political battles. In 2010, the Federal Communications Commission (the regulatory body of the United States of America) adopted the Open Internet Order with the intention of maintaining net neutrality (Gilroy, 2011), and in 2015 established a new Open Internet Oder that implemented strict net neutrality rules; however, two years later, in 2017, the same regulatory body repealed these rules in favor of the broadband internet companies (Kang, 2017). In 2010, the European Commission launched a series of public consultations on "the open internet and net neutrality in Europe" (European Commission, 2011) and after five years, the principle of net neutrality was legitimized in the European Union (EU) with the Regulation (EU) 2015/2120. It established common rules for safeguarding the equal and non-discriminatory treatment of traffic in the provision of internet access services and related end-users' rights. Before this decision, some EU member states formed their national policies to establish the principle of net neutrality and made appropriate decisions (Slovenia, the Netherlands). However, many other member states did nothing, including Lithuania.

Scholarly attention is mostly devoted to the making of a net neutrality policy in the United States of America and the European Union (a common EU policy and the national policies of member states with proactive features in the discussed field). Also, there are case studies focused on countries that were pioneers in the net neutrality policies, such as Norway or Chile, as well as countries with large markets (Brazil, India) (Marsden, 2016). However, there is a lack of research on the communications policies in those countries where the introduction of net neutrality was not preceded by national political agendas. Additionally, an insufficiently explored subject is the interaction of EU and member states' national communications policies agendas in the frame of the net neutrality issue. 
The Denationalization and Agencification of Net Neutrality Policy in Lithuania

The communications policy-making in Lithuania, specifically regarding net neutrality, in relation with the EU's policy and regulation, is examined in this paper. In particular, the paper focuses on reasoning why no national policy for establishing net neutrality rules was formulated in Lithuania.

\section{Features of Lithuanian Communications Policy and Multiple Streams Modeling}

The public policy of electronic communications in Lithuania is formulated by the Government of the Republic of Lithuania and the Ministry of Transport and Communications. The Information Society Development Committee under the Ministry of Transport and Communications (since the end of 2018 - under the Ministry of Economy) was assigned to participate in the shaping of state policy regarding information technologies and telecommunications. The Communications Regulatory Authority (CRA) (an independent national agency) is responsible for the implementation of the communications policy. According to the Law on Electronic Communications, the CRA has the right to provide suggestions for the Government (Ministry) regarding the policy of electronic communications. Some of the CRA suggestions are in the form of amendments to the drafted laws. In that way, the CRA is also involved in the formulation of policies.

The public policy regarding communications in Lithuania has been developed consistently since the restoration of State independence in 1990. Programs of the Lithuanian governments had respective chapters with clear directions of communications policy. The liberalization of the market, the expansion of the communications networks, and the privatization of state telecommunication company were characteristic features of the public policy in the last decade of the $20^{\text {th }}$ century.

Since 2000, when Lithuania started negotiations on the accession to the European Union, the national communications policy has been adjusted to fit the EU framework. When Lithuania became a member of the EU in 2004, the Law on Electronic Communications (2004), implementing the package of EU electronic communications directives, came into force (Directive 2002/22/EC etc.). Lithuanian public policy-makers enshrined the common legislative principles of the regulation of electronic communication activities, such as objectivity, transparency, and non-discrimination of regulation procedures. When Directive 2009/136/EC was adopted, its provision regarding an obligation for providers of electronic communications to provide information about conditions limiting end-users' access to the services was transferred to Lithuanian legislative acts. Leadership in the communications policy field regarding the adoption of the provisions of Directive 2009/136/EC has been taken over by the CRA, which registered a draft of amendments to the Law on Elec- 
tronic Communications in 2010. The same amendments of the legal act were subsequently submitted by the Ministry of Transport and Communications within a few months and adopted by the Lithuanian Parliament in 2011. Despite the fact that the Directive 2009/136/EC neither obligated nor prohibited the conditions limiting the end-users' access to internet services, a national net neutrality policy agenda was not important in Lithuania.

In order to analyze and explain why the national net neutrality policy was passively constructed in Lithuania, a multiple streams model (Kingdon, 1995; Zahariadis, 2003) was employed. The multiple streams model argues that there are three independent processes, or three streams (with their own structural rules and dynamics) in the political system: streams of political problems, politics, and policy solutions (Zahariadis, 2003; Herweg, Zahariadis, Zohlnhofer, 2017). Some problems are transformed into political problems (in the problems stream) when they are: (1) signaled by a relevant indicator, (2) related to attention-focusing events, (3) and/or defined, framed, and interpreted in a specific way that attracts the attention of the politicians and the society (Zahariadis, 2016; Herweg, 2017). The functioning of the politics stream depends on the election outcomes, the composition of parties in parliament and government, the balance of power of interest groups, and the so-called national mood. The latter means not only the changes of public opinion regarding some issue, but also how the political elites perceive that mood (Kingdon, 1995; Zahariadis, 2016). The stream of policy solutions are ideas, choices, or solutions developed by professionals in relatively small public policy communities (important civil servants, experts, representatives of interest groups and organizations). The functioning of this stream is usually decoupled from the ideologies, but the viability of proposed solutions depends on the fragmentation and support of the political community, the receptivity of elected decision-makers, as well as the resources and technical abilities available for implementing a political solution (Zahariadis, 2003; Herweg, 2017).

According to the multiple streams model, certain issues enter the political agenda when all three discussed streams are combined at certain critical political moments (Zahariadis, 2003). Kingdon (1995) named these moments as policy windows and defined short-term opportunities for advocates (politicians, lawyers, lobbyists, etc.) to provide the desired solutions or to draw the attention of key politicians to the issues they need to address. The windows of the political agenda can be opened in two streams out of three: political problems and politics (Herweg, Zahariadis, Zohlnhofer, 2017). In order to combine the streams of political problems, politics, and policy solutions, three necessary conditions must be met: (1) all three streams must be mature (that is, the problems, their decisions, and the corresponding policy actions must be sufficiently developed and the subjects of the streams have to be ready 
The Denationalization and Agencification of Net Neutrality Policy in Lithuania

for a change of the political agenda); (2) a public policy window must to be opened (this action is the result of changes at the streams of political problems and politics); (3) so-called policy entrepreneurs (or the advocates of proposed solutions) must be active to connect the streams (Herweg, 2017).

\section{Methodology}

This study applies the multiple streams model for the case of net neutrality policy in Lithuania and tests it based on a qualitative document analysis of the relevant legislative acts, reports of Lithuanian state and EU institutions, the Communications Regulatory Authority, monitoring companies and non-governmental organizations.

In order to determine whether the regulation of net neutrality became an attentionfocusing event or specifically defined in the public space (conditions of the political problems stream), a content analysis of the main Lithuanian news website Delfi.lt was conducted as well. Publications were selected using keywords regarding net neutrality and internet network penetration.

The period of the analysis is 2010-2015 - from launching the public consultations on "The Open Internet and Net Neutrality in Europe" by the European Commission and up to adoption of Regulation (EU) 2015/2120.

\section{Broadband Internet Development and Silenced Net Neutrality Issue}

When we elaborate the political process in the stream of political problems, it should be noted that the existence of an economic and/or technical indicator does not automatically transfer to a political problem. First of all, a particular indicator should reach a certain level and signal a social change or be significant in a particular social context. This could draw the attention of the public and the politicians, which would make it possible for the problem to enter the political agenda. Second, a certain indicator may be linked to a focusing event, or the event itself may be the cause of a change in the political agenda. This also requires an appropriate interpretation and framing of the event in the public space. According to the multiple streams model (Zahariadis, 2003), under these discussed conditions, it is possible to open up a public policy window in the stream of political problems, and the governmental agenda can then be turned into a decision-making agenda.

Indicators that measure net neutrality (the equality of internet flows, devices, services, and applications) and their level that can lead to social reactions (and the changes of political agendas) are related to technical (the amount of data and speed 
of internet flows) and economic (charge for web traffic and speed) indicators. When analyzing the problem of net neutrality in a wider context, it is important to assess the following factors: changes of broadband internet penetration rate in a particular geographical area, the competition in the market, and the availability of internet delivery technologies for consumers. In 2011, the largest Dutch internet service provider KNP revealed a plan to surcharge the Voice over Internet Protocol (Skype) and the smartphone application WhatsApp traffic; until then, in 2009, there were fixed cases regarding the throttling of peer-to-peer traffic by the second-largest cable operator UPC (van Eijk, 2014). It caused "a political storm" in the Netherlands (European Economic and Social Committee, 2012: 143). Consequently, in 2012, the Parliament of The Netherlands adopted law amendments to protect the principles of open internet and net neutrality (Marsden, 2016). Thus, a change in the economic indicator and the focusing of public attention to these events fostered an opening of a window in the stream of political problems and a turning point in the decisionmaking agenda.

In the case of Lithuanian indicators, at first we have to emphasize the consistent development of broadband internet in Lithuania and focus on the next generation access (NGA) networks. The fiber-optic communication lines (FTTP) became the main NGA technology in the provision of broadband internet services in Lithuania since 2009. Lithuania was ranked first in the Europe and fifth in the world according to fiber-optic broadband network development in terms of household penetration in the end of 2009 (Communications Regulatory Authority of the Republic of Lithuania, 2010). Lithuania retained its leading position in Europe regarding the development of FTTP (in terms of household penetration) until 2016 (IDATE Consulting, 2011-2016). Results of the total overall NGA (FTTP, VDSL, and DOCSIS 3.0 technology) coverage by country showed that Lithuania was ranked fifth in Europe in 2015. The NGA networks passed $97.5 \%$ of households across Lithuania (the EU average being $70.9 \%$ ) and $84.4 \%$ of rural households (the EU average being only $27.8 \%$ ) in 2015 (VVA Consulting, 2016).

Such an expansion of NGA networks enabled Lithuanian residents to get access to one of the fastest internet in the European Union. Lithuania, alongside Belgium, Bulgaria, the Netherlands, and Romania were the most advanced EU member states in terms of access to a very high speed broadband, with more than $20 \%$ of lines being at least $30 \mathrm{Mbps}$ (download) in 2011 (European Commission. Information Society and Media Directorate-General, 2011). Another important point is that Lithuania had the third-fastest actual download and upload speed of the FTTP technology during the peak periods of 14 European countries studied in 2012 (Sam Knows Limited, 2013). Moreover, Digital Agenda Scoreboard (2014) data shows that the fast broadband internet networks were most widely used in Belgium, the Netherlands, and Lithuania in 2014. 
In addition to the high penetration and fast speed of broadband internet, it is also important to note the competitiveness of the FTTP broadband internet market in Lithuania. Not only the main player TEO LT, but also other participants of the electronic communications market (internet and cable TV providers) had invested in fiber-optic communications lines. According to the data of the CRA, there were 55 providers of electronic communications services capable to offer FTTP for its users in the end of 2009 (Communications Regulatory Authority of the Republic of Lithuania, 2010). Almost half of the market share of the fixed broadband internet subscriptions in Lithuania had new market entrants in 2014 (Digital Agenda Scoreboard, 2014). This denotes a particularly viable level of competitiveness in the fixed broadband market. Despite some mergers of companies in the fixed broadband internet market in 2015, competition in the whole broadband internet market was fostered by the providers of mobile internet with the creation of LTE wireless networks. Moreover, fixed broadband networks in rural areas (unattractive for private business entities) have begun to be developed by the state-owned public company Plačiajuostis Internetas using EU funding since 2007. This public company provides wholesale broadband services for the commercial broadband players.

A comparative analysis of EU member states' data regarding the charging of internet traffic shows that median prices of the broadband internet access with a high download speed were lowest in Lithuania among EU countries in 2012 (European Commision. Directorate-General for Communications Networks, Content and Technology, 2013). Besides, median prices of broadband access for a standalone offer (with a download speed between 30 and $100 \mathrm{Mbps}$ ) were the lowest in Romania and Lithuania in EU in 2014. Another important and economically advantageous indicator for the Lithuanian population is that the share of broadband access cost (standalone offer, download speed between 12 and $30 \mathrm{Mbps}$ ) in the disposable income was one of the lowest in the EU (together with the Netherlands and the UK) - a little bit more than 1 percent from the income (Digital Agenda Scoreboard, 2014).

Therefore, it can be claimed that the effective development of broadband internet communications, the sufficient competitiveness of the market, the provision of a fast internet access and the relatively low prices for these services (the technical and economic indicators) created the basic conditions for keeping the window of the net neutrality problem closed in the stream of political problems and not forcing the national agenda of net neutrality policy in Lithuania. However, as case of the Netherlands (where previously discussed technical and economic indicators of internet traffic were similar to Lithuanian indicators) demonstrates, such conditions are necessary but not sufficient for keeping the net neutrality problem out of the political agenda. The reason which provoked the adoption of the net neutrality law in the Netherlands was the publicity of internet service providers' plans and their actions 
Medij. istraž. (god. 25, br. 2) 2019. (29-43)

in discriminating users' rights to get equal access to all types of internet traffic (van Eijk, 2014).

The data of Lithuanian internet traffic monitoring shows that there were some actions taken by several internet service providers with aims to limit the speed of video streaming (European Economic and Social Committee, 2012). However, such a behavior of the internet business entities did not receive any publicity and did not generate any event-focusing public attention. Also, it should be mentioned that the Lithuanian internet service providers did not apply any measures related to charging extra for voice over internet protocol services or another internet communication traffic. Thus, the emergence of the net neutrality problem in the public and policy agenda was avoided (i.e., in the problems stream with the open policy window).

A content analysis of the main Lithuanian internet website Delfi.lt (period 20102015) showed that the net neutrality problem received very little attention in the media. Net neutrality was mentioned a few times as an additional subtopic in publications about the development of internet business and the regulation of illegal gambling on the internet. On the other hand, the conducted content analysis demonstrated a focused and frequent media attention on the Lithuanian leadership in Europe regarding fiber-optic internet network penetration and the very good opportunities that residents have to use the fast speed internet.

Therefore, it can be stated that a policy window in the problems stream (regarding the net neutrality issue) was not opened, since neither a specific problem was signaled by an indicator, nor there was a public attention-focusing event in Lithuania between 2010 and 2015 .

\section{Passive National Policy at Opening the EU Policy Window}

A content analysis of the governmental documents (the Lithuanian Government programs, plans of implementation of the Government programs, strategic and annual plans of the Ministry of Transport and Communications and the Information Society Development Committee) (Lrv.lt, 2019; Sumin.lrt.lt, 2019; Ivpk.lrv.lt, 2019) covering the period between 2010 and 2015 showed that the state institutions took obligations to develop a broadband infrastructure in the rural areas. However, none from the examined documents mentioned issues of the open internet and net neutrality. Additionally, a content analysis of the legislative documents gathered using the Lithuanian Parliament' search engine for legal acts and drafted legal acts (Lrs.1t, 2019) between 2010 and 2015 showed that the notion of net neutrality was referred in two cases only. First, the CRA and the Ministry of Transport and Communications mentioned the principle of net neutrality in the explanatory notes of legal projects that intended to adopt the provisions of Directive 2009/136/EC into 
national law in 2010 and 2011. However, in this case, the principle of net neutrality was bypassed: there was an opportunity left for the internet service providers to limit certain services for customers (with the obligation to inform users about any such limitation). The notion of net neutrality was introduced for the second time in 2014 and 2015: during the legislative discourse (process), an argument by liberal politicians (and interest groups related to the gambling business) was raised against the banning of websites with content of illegal gambling (as mentioned earlier, the same discourse had aroused a certain response in the media as well).

Thus, the main executive policy-makers (the Government, the Ministry of Transport, and the Communications and the Information Society Development Committee) did not insert the issue of net neutrality and open internet into the national governmental agenda in the stream of politics. Also, it can be claimed that the net neutrality and open internet issue was not formulated as a separate debatable problem in the decision-making agenda of the Lithuanian Parliament.

Finally, when we analyze the actions of the main players in the politics stream, it is important to note that the business interest groups (broadband network operators) were not interested in the implementation of the net neutrality principle in the market. A representative of the largest company TEO LT claimed that network neutrality does not need to be regulated in competitive markets (European Parliament Office in Lithuania, 2015). Consequently, the net neutrality issue was filtered out of the politics stream and the national policy agenda.

In a situation where the passive national net neutrality policy prevailed (more in line with the interests of business groups) and an opportunity window was only opened by the EU's public policy, the CRA became a key player in linking the national and European net neutrality policies. The influence of this regulatory agency has been significant for policy formulation, too. Moreover, the impact of the CRA on the national policy process has been reinforced by its membership in the Body of European Regulators for Electronic Communications (BEREC), which assists the European Commission in the implementation of the EU regulatory framework for electronic communications. According to Regulation (EC) 1211/2009, the BEREC should advise the European Parliament, the Council, and the Commission at their request or on its own initiative. Thus, national communications agencies that are involved in the EU policy formulation also gain more weight in the national policy field - an agencification of the policy formulation process is taking place.

A content analysis of the CRA annual reports (Communications Regulatory Authority of the Republic of Lithuania, 2011-2016) between 2010 and 2015 shows that besides the aforementioned leadership of the CRA in the process of adopting the norms of Directive 2009/136/EC to the national law, the CRA also participated in the activity of the BEREC working group, which prepared a document on the qual- 
ity of internet access services, taking into account the neutrality of networks. The representatives of the CRA prepared a part of the document that dealt with the methods of evaluating internet access services. Moreover, the contribution of the CRA to the formation of Lithuania's position on Regulation (EU) 2015/2120 is worth mentioning as well. Finally, this binding legislative act denationalized the policies of the member states regarding net neutrality.

Regulation (EU) 2015/2120 obligated the BEREC (in close cooperation with the Commission) to issue guidelines for the implementation of the obligations of national regulatory authorities that must promote the continued availability of nondiscriminatory internet access services. In connection with Regulation (EU) 2015/2120 and BEREC's Guidelines on the Implementation by National Regulators of European Net Neutrality Rules (BEREC, 2016), the CRA amended the Rules on the Provision of Electronic Communications Services (Communications Regulatory Authority of the Republic of Lithuania, 2017) and started to assess whether the internet service providers do not restrict internet access by blocking or slowing down specific applications or services.

\section{Discussion and Conclusions}

The relocation of EU legal norms into national law has become a common practice in the making of Lithuania's communications policy since the negotiations on the accession to the European Union began. Consequently, the EU's role of a policy assistant was extended to the area of net neutrality between 2010 and 2015, without any previous significant actions in the national agenda. The Lithuanian communications policy has become essentially denationalized, and the net neutrality policy issue has been framed in the context of the EU's policy. The denationalization of the net neutrality policy-making was harmonized with the agencification of the policy formulation stage.

It can be claimed that the role of national governments in communications policymaking remains symbolic. The absence of any clear ambition to have an open internet and net neutrality policy (this is shown by the findings in the case of Lithuania) and any exceptional policy orientation to the market development may pose a risk to the public interest of gaining equal access to informational services. The establishment of EU regulations meant to safeguard the equal and non-discriminatory treatment of internet traffic shows that the EU community policy is more capable of resisting the pressures of market and global corporations (more than many individual member states can manage this alone).

The application of the multiple stream model showed that none of the three necessary conditions (Herweg, 2017) for the combination of political streams (for the net 
The Denationalization and Agencification of Net Neutrality Policy in Lithuania

neutrality issue to become a problem on the national policy agenda) were met: political streams were not mature, conditions for opening a policy window were not created, and activities of the policy entrepreneurs were meagre. When the national political will is delivered into the hands of the EU's institutions, the only option for raising the issue of net neutrality in the national agenda is to open a window of opportunity in the political problems stream. However, the study results show that none of the specific technical and/or economic indicators signaled a relevant problem, and no attention-focusing events regarding net neutrality happened during the studied period.

The content analysis of a major internet news website revealed a periodical publishing of information that reflects the development of advanced internet networks. Part of this information appears as information subsidies (in the form of press releases received from internet business associations, state institutions, and agencies) with the aim of informing the public on how well-developed the Lithuanian internet market is. The domination of such information means that less attention is given to the public interest regarding proper (and critical) information on the regulation of the openness and neutrality of the internet. Any lack of critical publicity leaves fewer opportunities to foster attention-focusing events in the stream of political problems.

\section{REFERENCES}

BEREC (2016). BEREC Guidelines on the Implementation by National Regulators of European Net Neutrality Rules. Accessed 15 October 2018. https://berec.europa.eu/eng/document_register/subject_matter/berec/regulatory_best_practices/ guidelines/6160-berec-guidelines-on-the-implementation-by-national-regulators-of-european-net-neutrality-rules

Communications Regulatory Authority of the Republic of Lithuania (2010). Annual Report 2009. Accessed 20 October 2018. https://www.rrt.lt/istekliai/ataskaitosir-apzvalgos/veiklos-ataskaitos/

Communications Regulatory Authority of the Republic of Lithuania (2011-2016). Annual Reports 20010-2015. Accessed 20 October 2018. https://www.rrt.lt/ istekliai/ataskaitos-ir-apzvalgos/veiklos-ataskaitos/

Communications Regulatory Authority of the Republic of Lithuania (2017). Annual Report 2016. Accessed 20 October 2018. http://www.rrt.lt/en/reviews-and-reports/rrt-annual-repots.html

Digital Agenda Scoreboard (2014). Broadband markets. Accessed 18 October 2018. https://ec.europa.eu/digital-single-market/en/news/scoreboard-2014-trends-european-broadband-markets-2014 
Medij. istraž. (god. 25, br. 2) 2019. (29-43)

Directive 2002/22/EC of the European Parliament and of the Council of 7 March 2002 on universal service and users' rights relating to electronic communications networks and services (Universal Service Directive). O. J., L108, 24.04.2002, 51-77.

Directive 2009/136/EC of the European Parliament and of the Council of 25 November 2009 amending Directive 2002/22/EC on universal service and users' rights relating to electronic communications networks and services, Directive 2002/58/EC concerning the processing of personal data and the protection of privacy in the electronic communications sector and Regulation (EC) No $2006 / 2004$ on cooperation between national authorities responsible for the enforcement of consumer protection laws. O. J., L337, 18.12.2009, 11-16.

European Commission. Information Society and Media Directorate-General (2011). Communication committee. Working Document. Subject: Broadband lines in the EU: situation at 1 July 2011. Accessed 18 October 2018. http://www.ris.org/ uploadi/editor/1329829472cocom_broadband_july_2011.pdf

European Commission. Directorate-General for Communications Networks, Content and Technology (2013). Communications Committee. Working Document. Broadband lines in the EU: situation at 1 July 2012. Accessed 18 October 2018. https://ec.europa.eu/digital-single-market/en/news/report-broadband-lines-eu1st-july-2012

European Economic and Social Committee (2012). Opinion of the European Economic and Social Committee on the 'Communication from the Commission to the European Parliament, the Council, the Economic and Social Committee and the Committee of the Regions. The open internet and net neutrality in Europe'. O. J., C24, 28.1.2012, 139-145.

European Parliament Office in Lithuania (2015). Europos skaitmeninė rinka: liberalizavimo link? (European digital market: towards liberalization?). Accessed 18 October 2018. http://www.europarl.europa.eu/lithuania/lt/jūsų-paslaugoms/ europos-skaitmeninè-rinka-liberalizavimo-link

Regulation (EC) 1211/2009 of the European Parliament and of the Council of 25 November 2009 establishing the Body of European Regulators for Electronic Communications (BEREC) and the Office. O. J. L337, 18.12.2009, 1-10.

Regulation (EU) 2015/2120 of the European Parliament and of the Council of 25 November 2015 laying down measures concerning open internet access and amending Directive 2002/22/EC on universal service and users' rights relating to electronic communications networks and services and Regulation (EU) No $531 / 2012$ on roaming on public mobile communications networks within the Union. O. J., L310/1, 26.11.2015, 1-18.

Gilroy, A. (2011). Access to Broadband Networks: The Net Neutrality Debate. Congressional Research Service. Accessed 16 October 2018. https://www.every- 
The Denationalization and Agencification of Net Neutrality Policy in Lithuania

crsreport.com/files/20110311_R40616_81d4flaa5388126152dec6b5a2959691 d13f1145.pdf

Herweg, N. (2017). European Union Policy-Making - The Regulatory Shift in Natural Gas Market Policy. Palgrave Macmillan.

Herweg, N., Zahariadis, N., Zohlnhofer, R. (2017). The Multiple Stream Framework: Foundations, Refinements, and Empirical Applications. In. C. M. Weible, P. A. Sabatier (eds.), Theories of the Policy Process. Fourth edition, 17-53. Boulder, CO: Westview Press.

IDATE Consulting (2011-2016). FTTH/B Panorama 2011-2016. Accessed 20 October 2018. http://www.ftthcouncil.eu/resources/resources?category_id=6\& topic $=$ Market $\% 20$ Data\&p $=1$

Ivpk.Irv.lt (2019). Information Society Development Committee. Planavimo dokumentai (Planning documents). Accessed 10 January 2019. https://ivpk.lrv.lt/lt/ administracine-informacija/planavimo-dokumentai

Kang, C. (2017). F.C.C. Repeals Net Neutrality Rules. The New York Times, 12/14/2017. https://www.nytimes.com/2017/12/14/technology/net-neutralityrepeal-vote.html

Kingdon, J. W. (1995). Agendas, Alternatives, and Public Policies. $2^{\text {nd }}$ edition. New York: Harper Collins College Publishers.

Lrs.lt (2019). Seimas of the Republic of Lithuania. Search for legal acts and draft legal acts. Accessed 5 January 2019. https://e-seimas.Irs.lt/portal/documentSearch/lt

Lrv.lt (2019). Ankstesnès Vyriausybės (Previous Governments). Accessed 5 January 2019. http://lrv.lt/lt/apie-vyriausybe/ankstesnes-vyriausybes/po-1990-metu

Marsden, C. T. (2016). Comparative Case Studies in Implementing Net Neutrality: A Critical Analysis of Zero Rating. Scripted, 13 (1): 1-39.

Meinrath, S., Pickard, V. (2008). Transcending net neutrality: Ten steps toward an open internet. Journal of Internet Law, 12 (6): 11-21.

Picard, G., Pickard, V. (2017). Essential Principles for Contemporary Media and Communications Policymaking. University of Oxford, Reuters Institute for the Study of Journalism. Accessed 16 October 2018. https://reutersinstitute.politics. ox.ac.uk/our-research/essential-principles-contemporary-media-and-communications-policymaking

Republic of Lithuania Law on Electronic Communications (2004). Valstybès žinios, 2004-04-30, no. 69-2382.

Sam Knows Limited (2013). Quality of Broadband Services in the EU. March 2012. Accessed 22 October 2018. https://ec.europa.eu/digital-single-market/en/news/ quality-broadband-services-eu-march-2012 
Sumin.lrt.lt (2019). Ministry of Transport and Communications. Planavimo dokumentai (Planning documents). Accessed 7 January 2019. http://sumin.lrv.lt/lt/ administracine-informacija/planavimo-dokumentai

The United Nations General Assembly (1948). The Universal Declaration of Human Rights. Accessed 10 October 2018. http://www.un.org/en/universal-declaration-human-rights/

van Eijk, N. (2014). Net Neutrality in the Netherlands. Gyeongje Gyuje wa Beob (Journal of Law and Regulation), 7 (1): 146-162.

VVA Consulting (2016). Broadband Coverage in Europe 2015. Mapping progress towards the coverage objectives of the Digital Agenda. Accessed 22 October 2018. http://publications.europa.eu/resource/cellar/19da7288-9ac5-11e6-868c01aa75ed71a1.0002.01/DOC_1

Zahariadis, N. (2003). Ambiguity and Choice in Public Policy. Political Decision Making in Modern Democracies. Washington: Georgetown University Press.

Zahariadis, N. (2016). Setting the agenda on agenda setting: definitions, concepts, and controversies. In N. Zahariadis (ed.), Handbook of Public Policy: Agenda Setting, 1-24. Cheltenham: Edward Elgar Publishing. 


\section{Denacionalizacija i agencijski angažman u stvaranju politike net neutralnosti u Litvi}

\section{Deimantas Jastramskis}

\section{SAŽETAK}

Ovaj rad usredotočuje se na formiranje komunikacijske politike u Litvi, osobito u pogledu net neutralnosti. Istraživanje primjenjuje model višsestrukih struja (multiple stream model) za analizu uvjeta političkih procesa $i$ aktivnosti političkih sudionika. U radu se tvrdi kako je litvanska komunikacijska politika postala načelno denacionalizirana od ulaska zemlje u Europsku uniju. Pitanje politike net neutralnosti uklopljen je u kontekst politike EU-a, a nacionalna agenda politike net neutralnosti izgubila je na važnosti. Denacionalizacija donošenja politike net neutralnosti usklađena je s uključivanjem agencija $u$ njezino formiranje.

Ključne riječi: komunikacijska politika, net neutralnost, regulacija, širokopojasni internet, model višestrukih struja 